\title{
Effect of Cutting Type, Collection Time of Cutting, Plant Sex, Stem Wounding Method and Presence or Absence of Leaves on Rooting and Growth of Jojoba Shrub Cuttings
}

\author{
Ahmed M. Eed ${ }^{1}$ and Adam H. Burgoyne ${ }^{2}$ \\ Associate Professor ${ }^{1}$, Researcher ${ }^{2}$ \\ ${ }^{1}$ Jojoba Naturals Company \& Assoc. Professor of Horticulture \& Plant Tissue Culture \\ Department of Plant Production \\ College of Agriculture, Ibb University \\ Yemen. \\ ${ }^{2}$ Jojoba Naturals Company, \\ Montevideo, Uruguay.
}

\begin{abstract}
A series of six experiments were conducted with an objective of studying the effect of cutting type, collection time of cutting, plant sex, presence or absence of leaves and wounding method on the rooting and growth of jojoba shrub cuttings during 2016-2017 in the Jojoba Naturals Company greenhouses at Sana'a, Yemen. The cuttings were collected, prepared and planted under transparent plastic tunnel. Perlite medium and automatic mist irrigation were used in the propagation beds. Relative humidity was between 80-99\% and temperature range was not more than $40^{\circ} \mathrm{C}$. Different parameters of rooting and growth of rooted cuttings were determined. Semi-hardwood and softwood cuttings recorded higher rooting percentage $(77.77 \%$ \& $82.22 \%)$ respectively than hardwood cuttings $(26.11 \%)$. The cuttings collected in the spring season gave the greatest value of rooting compared to those collected in autumn and winter season. Presence of leaves on the cuttings within rooting time affected significantly the rooting percentage in comparison with the cuttings without leaves. However, plant sex and wounding method did not differ significantly in respect of rooting percentage of semi-hardwood cuttings. By this investigation, an efficient protocol including collection time of cuttings, rooting medium, plant hormone with its concentration, cutting type and rooting conditions was standardized. Thus, jojoba rooted cuttings would be produced in commercial quantities. As rooting success ratio of cuttings exceeds more than $90 \%$.
\end{abstract}

Key words: Jojoba Shrub, Plant Sex, IBA, Cutting, Wounding Method And Presence Of Leaves.

\section{INTRODUCTION}

Jojoba (Simmondsia chinensis (Link) Schneider) is a perennial woody shrub native to the semiarid regions of southern Arizona, southern California and northwestern Mexico. Jojoba is being cultivated to provide a renewable source of a unique high-quality oil. Jojoba seed contains a light-gold colored liquid wax ester which is the primary storage lipid of the plant [1]. This is unlike conventional oilseed crops, such as soybean, corn, olive, or peanut which produce oils as the primary storage lipid. Jojoba liquid wax makes up 50\% or more of the seed's dry weight. The physical properties of jojoba oil are: high viscosity, high flash and fire point, high dielectric constant, high stability and low volatility. Its composition is little affected by temperatures up to $300^{\circ} \mathrm{C}$. The extracted oil is relatively pure, non-toxic, biodegradable, and resistant to rancidity. Jojoba is propagated by sexual and vegetative methods.

In plant populations derived by sexual propagation, it is difficult to determine sex type in early stages of growth i.e., 3 - 4 years from germination, and plants are genetically variable, which affects growth uniformity, physiological characteristics, yield and early 
bearing [2]-[3]. Further, jojoba is biased towards male (5:1; male: female ratio) [4]. On the other hand, vegetative propagation methods provide genetically, uniform plant material with early fruiting. Successful rooting of jojoba cuttings can be achieved by the use of different auxins such as indole butyric acid (IBA), $\alpha$-naphthalene acetic acid (NAA) and indole-3-acetic acid (IAA). The rooting ratio of semi-hardwood cuttings was increased by IBA @ $1000 \mathrm{mg} / \mathrm{l}$ and the rooting ratio of young individuals was higher than the mature ones [5]. Clonal differences for rooting capability of semi-hardwood cuttings treated with $2000 \mathrm{mg} / \mathrm{l} \mathrm{IBA}$ under intermittent mist were evident among 12 clones of jojoba [6]. Reference [7] reported 30 to $70 \%$ rooting in terminal cuttings treated with $4000 \mathrm{mg} / \mathrm{l} \mathrm{IBA}$ using intermittent mist in a partially shaded greenhouse. Reference [8] rooted the cuttings of 20 different male jojoba plants by treating with $4000 \mathrm{mg} / \mathrm{l}$ IBA for fifteen "s," misting intermittently for eight "s," every four minutes.

Creating an atmosphere of $100 \%$ humidity at the leaf surface of jojoba stem cuttings, without saturating the rooting medium, had contributed to a high degree of rooting as in [9]. Reference [10] recorded rooting of jojoba cuttings within 3 to 5 weeks in a greenhouse with substrate temperature of $30^{\circ} \mathrm{C}$ and mist applied for 10 "s," every 8-10 minutes. Reference [11] recorded 61\% rooting in semi-hardwood cuttings of jojoba just dipped in $4000 \mathrm{mg} / \mathrm{lBA}$ solution under partially shaded polyethylene sheet tunnel having 90 to $95 \%$ humidity with mean temperature of $15-30^{\circ} \mathrm{C}$. We got previously rooting percentage of $37.33 \%$ and $66.23 \%$ of semihardwood cuttings when treated with IBA at $4000 \mathrm{ppm}$ in the sand and peat moss medium (1:1), and the mixture medium of peat moss, perlite and vermiculite (1:1:1) respectively [14\&15]. Therefore the objective of the present investigation was to evaluate the effect of cutting type on the rooting and growth of jojoba shrub cuttings which collected in different seasons. Exactly to develop and raise rooting percentage as a major and pivotal factor among different studied characters in the vegetative propagation of cuttings. Ultimately to standardize an efficient protocol for vegetative propagation of jojoba shrubs by using cuttings depending on the collection time of cuttings and using of suitable facilities as a general goal. Detailed goals of all experiments were determined as per experiment under.

\section{MATERIALS AND METHODS}

Six experiments were conducted in the greenhouses, Sana'a, Yemen, in 2016 and 2017. Plant materials were collected whole day from mother farm (four years age) in Al-jawf governorate, Al-saed region, Yemen and transferred to greenhouses at Sana'a in moistened hessian bags. Each bag contained 800-1000 cuttings. Eight days were consumed for collection of cuttings, transportation by car and planting process. All used cuttings were from female shrubs in all conducted experiments except plant sex experiment where half of used cuttings were male and the rest was female as per the purpose of the experiment. Different parameters such as rooting percentage, number of roots per rooted cutting, root length $(\mathrm{cm})$, height of rooted cutting, number of shoots and leaves per rooted cutting, were observed after 75 days from planting in the rooting medium. Dominant meteorological factors at Al-jawf governorate during 1986-1991 were depicted (Table 1) The detail of each experiment is written under.

Table 1 Dominant meteorological factors at Al-jawf governorate during 1986-1991.

\begin{tabular}{|l|l|l|l|l|l|l|l|l|l|l|l|l|}
\hline $\begin{array}{l}\text { Metrological } \\
\text { factors }\end{array}$ & Jan & Feb & March & April & May & June & July & Aug & Sep & Oct & Nov & Dec \\
\hline $\begin{array}{l}\text { Temperature } \\
\text { Max. }\end{array}$ & 28.0 & 30.8 & 33.5 & 34.8 & 38.2 & 39.8 & 40.2 & 36.6 & 37.7 & 33.3 & 29.7 & 27.2 \\
\hline $\begin{array}{l}\text { Temperature } \\
\text { Min. }\end{array}$ & 11.0 & 14.6 & 18.2 & 19.2 & 21.8 & 23.5 & 25.5 & 25.0 & 21.9 & 17.9 & 12.6 & 10.7 \\
\hline $\begin{array}{l}\text { Relative } \\
\text { humidity (\%) }\end{array}$ & 35 & 32 & 32 & 33 & 21 & 19 & 22 & 24 & 20 & 17 & 20 & 28 \\
\hline $\begin{array}{l}\text { Wind speed } \\
\text { (m/s) }\end{array}$ & 2.5 & 2.6 & 2.7 & 2.5 & 2.6 & 3.0 & 3.6 & 3.3 & 2.4 & 2.3 & 2.0 & 2.0 \\
\hline $\begin{array}{l}\text { Rainfall } \\
\text { (mm/month) }\end{array}$ & 12 & 4.4 & 17.7 & 14.5 & 3.0 & 18.0 & 4.3 & 2.0 & 2.2 & 1.2 & 0.6 & 6.6 \\
\hline
\end{tabular}

Temperature measured as celsius, Values are mean of several years.

\subsection{Experiment 1}

Three hundred and three cuttings; softwood, semi-hardwood and hardwood cuttings were collected, moved and planted in the shade house in November 2016. The leaves from basal nodes of the cuttings were trimmed off. Shoot tip with one pair of leaves were left on 
each cutting. The basal portion with no leaves of the cuttings was longitudinally wounded with a sterile and sharp razor in two to three places and then dipped for 15 second in IBA solution with a fixed concentration of $4000 \mathrm{ppm}$ (part per million). The treated cuttings were inoculated in the rooting medium composed of perlite only under plastic transparent tunnel conditions in the shade house (80\% shade). Cuttings were irrigated daily twice by the use of mist irrigation system for providing cuttings the suitable humidity. Humidity range was between $90-99 \%$ and temperature was not more than $37{ }^{\circ} \mathrm{C}$. The temperature and humidity were measured with HygroThermometer device (Jumbo Display Hygro-Thermometer, USA). The cuttings were kept from the end of November to the beginning of February. The experiment was conducted with aim of studying the effect of cutting type on the rooting and growth of jojoba shrub cuttings which collected in the autumn season (November).

\subsection{Experiment 2}

Four hundred forty seven cuttings; softwood, semi-hardwood and hardwood cuttings were collected, moved and planted in the shade house in January 2017. The cuttings were kept from the beginning of January to the end of March. Transportation, preparation and planting, additional to other treatments for cuttings were done as in Experiment No. 1. The experiment was to assess the effect of cutting type on the rooting and growth of jojoba shrub cuttings which collected in the winter season (January).

\subsection{Experiment 3}

Hundred thirty five cuttings; softwood, semi-hardwood and hardwood cuttings were collected, moved and planted in the shade house in March 2017. The cuttings were kept from the beginning of March to the end of May. Transportation, preparation and planting additional to other treatments for cuttings were done as in Experiment No.1. The experiment was to find out the effect of cutting type on the rooting and growth of jojoba shrub cuttings which collected in the spring season (March).

\subsection{Experiment 4}

Ninety cuttings; softwood, semi-hardwood and hardwood cuttings were collected, moved and planted in the shade house in March 2017. The experiment was carried out with objective of study the effect of presence or absence of leaves on the cuttings on the rooting and growth of jojoba cuttings. Cuttings were prepared and treated as with those in the Experiment No.1 except half of total cuttings were planted without leaves.

\subsection{Experiment 5}

Ninety semi-hardwood cuttings were collected, moved and planted in the shade house in March 2017. The experiment was conducted to find out the effect of wounding method either direct beat by sterilized scalpel for 2-3 times or longitudinal wounding in 2-3 places on the cutting bark on the rooting and growth of cuttings. Cuttings also were prepared and treated as those in the Experiment No.1.

\subsection{Experiment 6}

Five thousand nine hundred thirty cuttings from male jojoba shrubs and 690 cuttings from female jojoba shrub were collected, moved and planted in the shade house in March 2017. The experiment was designed to study the effect of plant sex; male or female on the rooting and growth of jojoba shrub cuttings. Extra preparation and treatments of cuttings were done as in Experiment No. 1.

\subsection{Experimental design \& Statistical analysis}

Experiments were conducted in one way experiment; randomized complete block design (RCBD) with three or five replicates as per experiment, each with varied number of rooted cuttings per replicate. Obtained data of different parameters of rooted jojoba cuttings were subjected to statistical analysis according to [12] \& [13]. ANOVA values were obtained with Opstat1 software (O.P Sheron, Programmer, Computer Section, CCS HAU, Hisar, India) and means were separated with least significant difference (LSD) at P = 0.05. Further, comparison between cuttings with or without leaves, male and female plants and methods of wounding and direct beat on bark of cuttings on rooting and growth at parameters studied was achieved independently according to Systat software, version 10, SPSS, Ine. 2000, by calculating T-test at $\mathrm{P}=05 \%$.

\section{RESULTS AND DISCUSSION}

As per research goals, results came compatible with the goals. In general, a series of experiments were carried out by collecting various type of stem cuttings (softwood, semi-hardwood \& hardwood) at different times of year; November (autumn), January (winter) and March (spring) in order to study the effect of cutting type, plan sex, presence or absence of leaves, cutting wounding method and collection time of cuttings on the rooting and growth of jojoba cuttings. 
Table 2 shows the effect of cutting type on rooting and growth of softwood, semi-hardwood \& hardwood cuttings of jojoba shrubs, November collection. In general, semi-hard wood cuttings recorded the highest values and differed significantly with hardwood cuttings at all parameters studied except with number of leaves per rooted cutting where no significant effect was seen between both. However, soft wood cuttings came in the second rank after semi-hardwood cuttings in its response for rooting and growth characters except with rooting percentage character. It is observed generally that range of rooting cuttings was low for the three kind of cuttings, this may be due to importance of determination of suitable collection time of cuttings; these cuttings of this experiment were collected in the autumn season which comes after summer season, in summer season almost all growth aspects are not available due to unsuitable conditions such as continuous move of dusty wind within June, July, August and September (Table 1). (Table 1 was used to interpret collection time findings in November, January and March experiments because of no availability of meteorological factors data in the experiments time) Therefore, internal contents of collected cuttings in the November are poor in nutrient and indogenus hormones. In addition, vegetative growth is also poor.

Table $2 \mathrm{E}$ ffect of type of cutting on rooting and growth of softwood, semi-hardwood and hardwood cuttings of jojoba (Simmondsia chinensis) shrub, collected in November.

\begin{tabular}{|l|l|l|l|l|l|l|l|}
\hline $\begin{array}{r}\text { Type of } \\
\text { cutting }\end{array}$ & $\begin{array}{r}\text { No. of } \\
\text { used } \\
\text { cuttings }\end{array}$ & $\begin{array}{r}\text { Rooting } \\
\text { percentage } \\
\text { (\%) }\end{array}$ & $\begin{array}{l}\text { No. of } \\
\text { roots/ } \\
\text { rooted } \\
\text { cutting }\end{array}$ & $\begin{array}{l}\text { Root } \\
\text { length } \\
\text { (cm) }\end{array}$ & $\begin{array}{l}\text { Height of } \\
\text { rooted } \\
\text { cutting } \\
\text { (cm) }\end{array}$ & $\begin{array}{l}\text { No. of } \\
\text { leaves/ } \\
\text { rooted } \\
\text { cutting }\end{array}$ & $\begin{array}{l}\text { No. of } \\
\text { shoots/ } \\
\text { rooted } \\
\text { cuttings }\end{array}$ \\
\hline Softwood & 42 & $26.18 \mathrm{a}$ & $7.00 \mathrm{~b}$ & $2.86 \mathrm{~b}$ & $13.03 \mathrm{~b}$ & $4.80 \mathrm{a}$ & $1.16 \mathrm{a}$ \\
\hline $\begin{array}{l}\text { Semi- } \\
\text { hardwood }\end{array}$ & 225 & $25.67 \mathrm{a}$ & $11.66 \mathrm{a}$ & $3.50 \mathrm{a}$ & $20.33 \mathrm{a}$ & $5.00 \mathrm{a}$ & $1.30 \mathrm{a}$ \\
\hline Hardw ood & 36 & $17.66 \mathrm{~b}$ & $4.00 \mathrm{c}$ & $1.83 \mathrm{c}$ & $9.16 \mathrm{c}$ & $3.00 \mathrm{a}$ & $1.00 \mathrm{~b}$ \\
\hline C.V & & 7.93 & 11.67 & 11.94 & 8.66 & 18.75 & 5.76 \\
\hline
\end{tabular}

*Similar letters indicate means which are not significantly differ ent (LSD, $P=0.05$ ).

C.V indicates coefficient of variation \& values represent means.

Table 3 indicates the effect of cutting type on the rooting and growth of softwood, semi-hardwood and hardwood cuttings of jojoba shrubs, January collection. It is observed clearly from data in this table that semi-hard wood cuttings gave almost the greatest values of all parameters investigated compared with softwood and hardwood cuttings except with softwood cuttings at rooting percentage character where it was lower than softwood cuttings but with no significance effect. It is noticed that behavior of cuttings with respect to rooting and growth aspects are almost similar to that showed in the Table 1. Also it is observed increasing in rooting percentage in January collection of the three type of cuttings; softwood, semi-hardwood and hardwood (65.76\%, 63.47\% and $22.18 \%$ respectively). This is due to improvement of food status of mother plants in the autumn months because of stopping of dusty wind movement and decreasing of air temperature (Table 1). This is also being in line with our previous result when we got $66.23 \%$ of rooting percentage from semi-hardwood cuttings which collected before summer season. 
International Journal of Advances in Scientific Research and Engineering (ijasre), Vol 5 (10), October-2019

Table 3 Effect of type of cutting on rooting and growth of softwood, semi-hardwood and hardwood cuttings of jojoba (Simmondsia chinensis) shrub, collected in January.

\begin{tabular}{|l|l|l|l|l|l|l|l|}
\hline $\begin{array}{r}\text { Type of } \\
\text { cutting }\end{array}$ & $\begin{array}{r}\text { No. of } \\
\text { used } \\
\text { cuttings }\end{array}$ & $\begin{array}{r}\text { Rooting } \\
\text { percentage } \\
(\%)\end{array}$ & $\begin{array}{l}\text { No. of } \\
\text { roots/ } \\
\text { rooted } \\
\text { cutting }\end{array}$ & $\begin{array}{l}\text { Root } \\
\text { length } \\
(\mathbf{c m})\end{array}$ & $\begin{array}{l}\text { Height of } \\
\text { rooted } \\
\text { cutting } \\
\text { (cm) }\end{array}$ & $\begin{array}{l}\text { No. of } \\
\text { leaves/ } \\
\text { rooted } \\
\text { cutting }\end{array}$ & $\begin{array}{l}\text { No. of } \\
\text { shoots/ } \\
\text { rooted } \\
\text { cuttings }\end{array}$ \\
\hline Softwood & 69 & $65.76 \mathrm{a}$ & $6.66 \mathrm{~b}$ & $2.50 \mathrm{~b}$ & $9.66 \mathrm{~b}$ & $5.50 \mathrm{~b}$ & $1.00 \mathrm{a}$ \\
\hline $\begin{array}{l}\text { Semi- } \\
\text { hardwood }\end{array}$ & 330 & $63.47 \mathrm{a}$ & $13.33 \mathrm{a}$ & $5.00 \mathrm{a}$ & $15.66 \mathrm{a}$ & $10.23 \mathrm{a}$ & $1.16 \mathrm{a}$ \\
\hline Hardwood & 48 & $22.18 \mathrm{~b}$ & $4.00 \mathrm{~b}$ & $3.50 \mathrm{~b}$ & $11.33 \mathrm{~b}$ & $5.83 \mathrm{~b}$ & $1.16 \mathrm{a}$ \\
\hline C.V & 14.95 & 16.13 & 12.44 & 14.43 & 17.25 & 12.00 \\
\hline
\end{tabular}

*Similar letters indicate means which are not significantly different (LSD, $P=0.05$ ).

C.V indicates coefficient of variation \& values represent means.

The data are shown in the Table 4 and Fig. 1 indicate effect of cutting type on rooting and growth of softwood, semi-hardwood and hardwood cuttings of jojoba shrubs, March collection. Softwood and semi-hardwood cuttings recorded significantly higher rooting percentage $(82.22 \%$ \& $77.77 \%$ respectively) over hardwood cuttings $(26.11 \%)$ whereas no significance effect was observed between softwood cuttings and semi-hardwood cuttings in this character. In addition, we have raised rooting percentage up to more than $90 \%$ from semi-hardwood cuttings in commercial production of jojoba rooted cuttings when the cuttings were collected in the March (data not shown) because we have considered semi-hardwood cuttings are the most suitable cuttings for rooting. Root length was greater $(10.99 \mathrm{~cm})$ with softwood cuttings than the other two type of cuttings; semi-hardwood and hardwood respectively $(7.02 \mathrm{~cm} \mathrm{\&} 6.66 \mathrm{~cm})$ with significant difference. However, hardwood cuttings showed higher values for number of roots, plant height, number of shoots and leaves per rooted cutting compared to softwood and semi-hardwood cuttings. This may be due to cuttings age and increasing of shoots number per rooted cuttings (Fig. 1).

Table 4 Effect of type of cutting on rooting and growth of softwood, semi-hardwood and hardwood cuttings of jojoba (Simmondsia chinensis) shrub, collected in March.

\begin{tabular}{|l|l|l|l|l|l|l|l|}
\hline $\begin{array}{r}\text { Type of } \\
\text { cutting }\end{array}$ & $\begin{array}{r}\text { No. of } \\
\text { used } \\
\text { cuttings }\end{array}$ & $\begin{array}{r}\text { Rooting } \\
\text { percentage } \\
(\%)\end{array}$ & $\begin{array}{l}\text { No. of } \\
\text { roots/ } \\
\text { rooted } \\
\text { cutting }\end{array}$ & $\begin{array}{l}\text { Root } \\
\text { length } \\
(\mathbf{c m})\end{array}$ & $\begin{array}{l}\text { Height of } \\
\text { rooted } \\
\text { cutting } \\
\text { (cm) }\end{array}$ & $\begin{array}{l}\text { No. of } \\
\text { leaves/ } \\
\text { rooted } \\
\text { cutting }\end{array}$ & $\begin{array}{l}\text { No. of } \\
\text { shoots/ } \\
\text { rooted } \\
\text { cuttings }\end{array}$ \\
\hline Softwood & 45 & $82.22 \mathrm{a}$ & $9.70 \mathrm{~b}$ & $10.99 \mathrm{a}$ & $21.44 \mathrm{~b}$ & $5.55 \mathrm{c}$ & $1.00 \mathrm{~b}$ \\
\hline $\begin{array}{l}\text { Semi- } \\
\text { hardwood }\end{array}$ & 45 & $77.77 \mathrm{a}$ & $14.96 \mathrm{a}$ & $7.02 \mathrm{~b}$ & $25.25 \mathrm{ab}$ & $8.58 \mathrm{~b}$ & $1.20 \mathrm{~b}$ \\
\hline Hardwood & 45 & $26.11 \mathrm{~b}$ & $15.00 \mathrm{a}$ & $6.66 \mathrm{~b}$ & $28.00 \mathrm{a}$ & $14.50 \mathrm{a}$ & $3.33 \mathrm{a}$ \\
\hline C.V & 9.35 & 11.56 & 13.97 & 7.42 & 11.75 & 22.53 \\
\hline
\end{tabular}

*Similar letters indicate means which are not significantly different (LSD, P = 0.05).

C.V indicates coefficient of variation \& values represent means. 


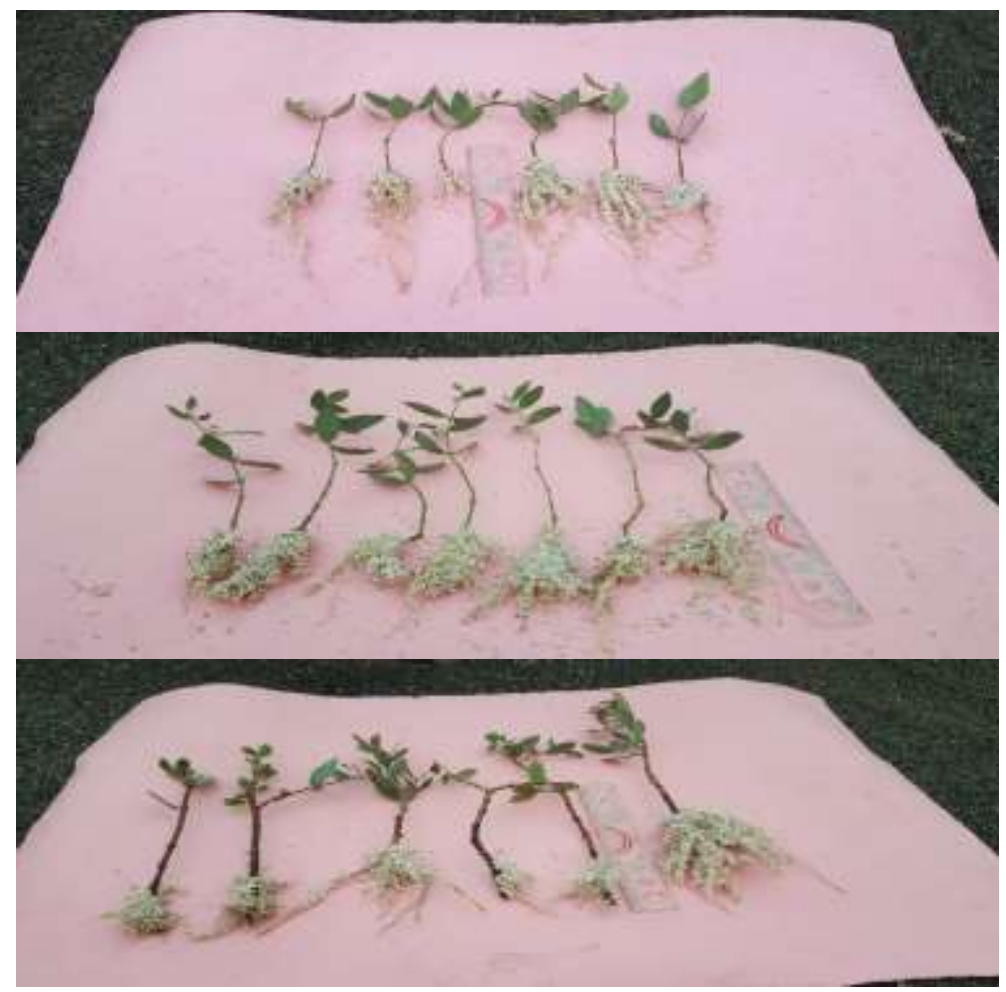

Figure 1 Rooted Softwood, Semi-Hardwood and Hardwood Cuttings as Affected wth Cutting Type and Collection Time; March Collection.

Comparison among effect of collection time, cutting type and their interaction on rooting percentage of jojoba shrub cuttings as depicted in Table 5. Collection time affected significantly rooting percentage of cuttings irrespective of cutting type as it reached $62.03 \%$ in the March (spring season) collection compared to November (autumn season) and January (winter season) collections (23.17\% \& 50.47\% respectively) (Table 5). Whereas softwood and semi-hardwood cuttings obtained significantly greater rooting percentage $(58.05 \%$ \& $55.64 \%)$ in comparison with the hardwood cuttings $(21.98 \%)$ irrespective of the collection time. On the same trend, softwood and semi-hardwood cuttings got significantly more values of rooting percentage in the March collection followed by January collection and then November collection compared to hardwood cuttings at all collections time. On the other hand, the best result of rooting percentage of jojoba cuttings was obtained by softwood and semi-hardwood cuttings $(82.22 \%$ \& $77.77 \%)$ in the March collection in comparison with the collection time of January $(65.76 \%$ \& 63.47\%) and November $(26.18 \%$ \& $25.67 \%)$ with respect to the same type of cuttings; softwood and semi-hardwood, all respectively. Hardwood cuttings recorded the least values of rooting percentage compared to softwood and hardwood cuttings at all collections time (March;26.11\%, January;22.18\% \& November; $17.66 \%$ respectively). In addition, November collection time of the three types of used cuttings did not differ significantly with the collection time at January and March. 
International Journal of Advances in Scientific Research and Engineering (ijasre), Vol 5 (10), October-2019

Table 5 Comparison among effect of collection time, cutting type and their interaction on rooting percentage of jojoba shrub cuttings.

\begin{tabular}{|c|c|c|c|c|}
\hline \multicolumn{5}{|c|}{ Rooting percentage (\%) } \\
\hline \multirow[t]{3}{*}{ Collection time (CT) } & \multicolumn{3}{|c|}{ Interaction between CUT x CT ${ }^{2}$} & CT mean ${ }^{1}$ \\
\hline & \multicolumn{3}{|c|}{ Cutting type (CUT) } & \\
\hline & Softwood & $\begin{array}{l}\text { Semi- } \\
\text { hardwood }\end{array}$ & Hardwood & \\
\hline November & $26.18 \mathrm{c}$ & $25.67 \mathrm{c}$ & $17.66 \mathrm{c}$ & $23.17 \mathrm{~b}$ \\
\hline January & $65.76 \mathrm{~b}$ & $63.47 \mathrm{~b}$ & $22.18 \mathrm{c}$ & $50.47 \mathrm{~b}$ \\
\hline March & $82.22 \mathrm{a}$ & $77.77 \mathrm{a}$ & $26.11 \mathrm{c}$ & $62.03 \mathrm{a}$ \\
\hline CUT mean ${ }^{1}$ & $58.05 \mathrm{a}$ & $55.64 \mathrm{a}$ & $21.98 \mathrm{~b}$ & \\
\hline
\end{tabular}

*Similar letters indicate means which are not significantly different (LSD, $\mathrm{P}=0.05)$. ${ }^{1}$ Comparisons are made among CUT means, and among CT means separately.

${ }^{2}$ Comparison made among interaction data between CUT \& CT. Values represent means.

Table 6 illustrates the effect of presence or absence of leaves on semi-hardwood cuttings on rooting and growth of jojoba shrub cuttings, March collection. It is noticed clearly that from all parameters studied, only two characters differed significantly with respect to presence or absence of leaves on the cuttings i.e. are rooting percentage and root length. On the other meaning, semi-hardwood cuttings with leaves gave significantly higher rooting percentage (62.33\%) than the same type of cuttings without leaves (33.33\%) as per T-test at probability 0.05 . On the same trend, semi-hardwood cuttings with leaves obtained significantly longer roots $(7.33 \mathrm{~cm})$ over the same type of cuttings without leaves $(6.00 \mathrm{~cm})$. This refers to that leaves synthesize food and transfer it to growth points of cuttings, this operation encourages early callus induction which is considered the first step for root formation and then its elongation, and the opposite case is with cuttings without leaves. However, the other parameters did not record significant effect between cuttings with or without leaves.

Table 6 Effect of presence or absence of leaves of semi-hardwood cuttings on rooting and growth of jojoba (Simmondsia chinensis) shrub cuttings, collected in March.

\begin{tabular}{|c|c|c|c|c|c|c|c|}
\hline Cutting & $\begin{array}{r}\text { No. of } \\
\text { used } \\
\text { cuttings }\end{array}$ & $\begin{array}{r}\begin{array}{r}\text { Rooting } \\
\text { percentage }\end{array} \\
(\%) \\
\text { Mean } \pm \text { SD }^{1}\end{array}$ & $\begin{array}{l}\text { No. of } \\
\text { roots/ } \\
\text { rooted } \\
\text { cutting }\end{array}$ & $\begin{array}{l}\begin{array}{l}\text { Root } \\
\text { length } \\
(\mathrm{cm})\end{array} \\
\text { Mean } \pm \mathrm{SD}^{1}\end{array}$ & 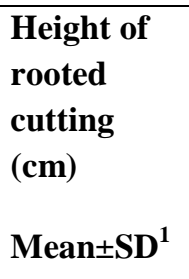 & 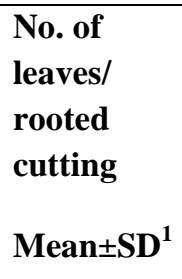 & 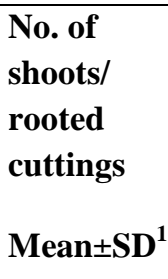 \\
\hline $\begin{array}{l}\text { Cutting with } \\
\text { leaves }\end{array}$ & 45 & $62.33 \pm 6.42$ & $7.33 \pm$ & $5.33 \pm 0.57$ & $19.00 \pm 1.00$ & $3.66 \pm$ & $1.00 \pm 0.10$ \\
\hline $\begin{array}{l}\text { Cutting without } \\
\text { leaves }\end{array}$ & 45 & $33.33 \pm 7.63$ & $6.00 \pm$ & $1.06 \pm 0.15$ & $17.33 \pm 1.52$ & $5.00 \pm$ & $2.33 \pm 1.04$ \\
\hline T-test 0.05 & & $*$ & NS & $*$ & NS & NS & NS \\
\hline
\end{tabular}

${ }^{\mathrm{T}}$ SD indicates standard deviation. * Refers to significant difference for studied character by using T-test at $P .0 .05$. NS indicates none significance. 
Regarding the effect of wounding method of cuttings either direct cut or wounding by removing rectangular pieces of bark on rooting and growth of jojoba shrub cuttings, collected in March. The result is presented briefly in the Fig. 2. As it is seen in the figure, no significant difference was observed between both kind of cuttings; either which was wounded by direct cut or the other one which wounded by removing rectangular pieces of cutting bark from three places with respect to all parameters studied. This may be referring to that, the wounding of cutting bark is done whether by direct cut or by wounding which resulted in root callus induction and then followed by inducing roots.

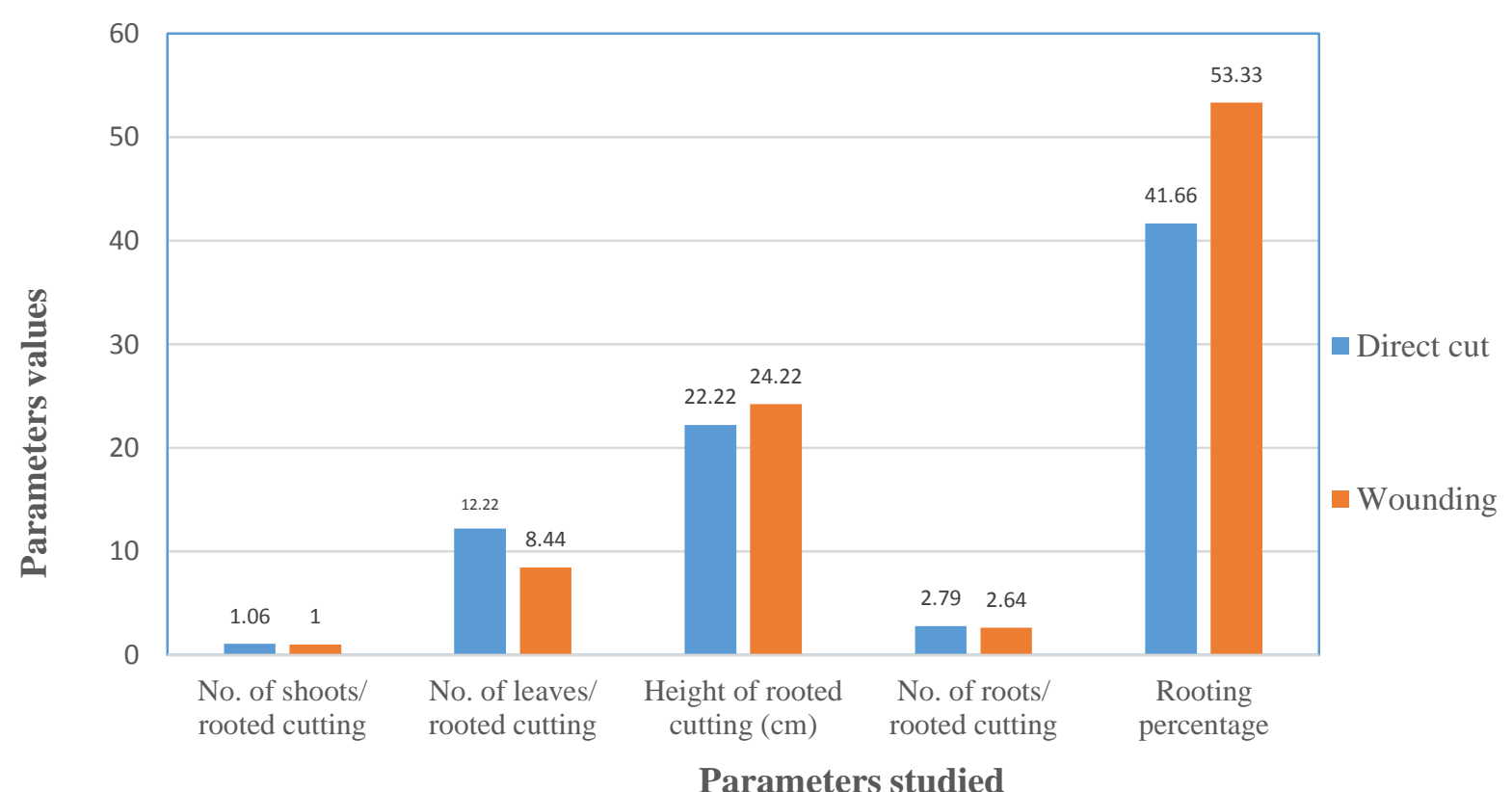

Figure 2: Effect of Wounding Method of Cuttings on Rooting and Growth of Jojoba Shrub Cuttings, Collected in March

Pertaining to the effect of plant sex either male or female on rooting percentage of jojoba semi-hardwood cuttings shrub, it is shown in the Fig. 3 male sex for semi-hardwood cuttings gave more rooting percentage (58.42\%) than female sex for same type of cuttings (55.44\%) with no significant difference. In fact, absence of significance between male and female semi-hardwood cuttings is due to no morphological difference between male and female plants is observed except at flowering and rooting stages. On the other hand, similarity between both sexes is almost absolutely, thus it gave similar response for different operations such as root induction.

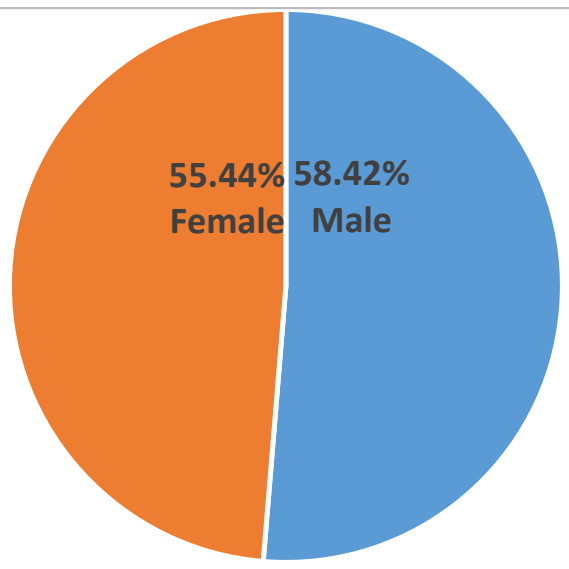

Figure 3 Effect of Plant Cutting Sex on Rooting Percentage of Semi-hardwood Cuttings of Jojoba (Simmondsia cheninsis) Shrub, Collected in March 


\section{CONCLUSIONS}

The best time for collecting jojoba cuttings to get the highest rate of rooting was in March and the best type of cuttings for the previous goal was softwood and semi-hardwood cuttings. An optimum rooting medium was the perlite. Automatic mist irrigation inside tunnel was important in this success. It is advised to use this protocol for commercial production of rooted cuttings from jojoba shrubs.

\section{ACKNOWLEDGMENTS}

The authors appreciate highly Jojoba Naturals Company for their kind support and cooperation during different stages at achieving this research.

\section{REFERENCES}

[1] J. Sardana, and A. Batra, "In vitro regeneration of jojoba (Simmondsia chinensis): a plant of high potential. Advances in Plant Sciences" vol. 11, no. 1, pp. 143 - 46, 1998.

[2] H. A. A. Mohasseb, M. K. El-Bahr, Z. M. Adam, H. A. Moursy, and M. E. Solliman "In vitro clonal propagation (Simmondsia chinensis (Link) Schn) "Aust. J. of Basic \& Appl. Sci. vol 3, no 4, pp. 3128-3136, 2009.

[3] P. A. Roussos, A. Toila-Marioli, C. A. Pontikis, and D. Kotsias, "Rapid multiplication of jojoba seedlings by vitro culture" Plant Cell, Tissue and Organ Culture vol. 57, pp. 133-137, 1999. http://dx.doi.org/10.1023/A:1006316732621

[4] J. R. Al-Obaidi, B. K. Suliman, and N. K. Al-Ani, "Molecular-based marker for sex differentiation of jojoba in vivo and in vitro Iragi cultivars using RAPD-PCR technique" Sci. Res. and Essays vol. 7, no 7, pp. 522-527, 2012.

[5] B. Cao, and H. D. Gao, "Technology of cutting propagation of Simmondsia chinensis (Link) Schneider (in Chinese). J. Nanjing Forest. Univ., vol. 27, pp. 62-66, 2003.

[6] C. W. Lee, and D.A. Palzkill, "Propagation of jojoba by single node cuttings" HortScience, vol. 19, pp. 841-42, 1984.

[7] P. H. Thomson, "Jojoba Handbook (3rd ed.)" Bonsall Publications, Bonsall, California, U.S.A., pp. 57-162, 1982.

[8] W. R. Feldman, and D.A. Palzkill, "Effects of mode of transport and time of excision on rooting and early growth of jojoba cuttings" Pl. Propagator, vol. 32, pp. 4-6, 1986.

[9] J. H. Brown, and A. M. Campbell, "Practical and scientific aspects of vegetative propagation of jojoba cuttings using fog" in: Proc. of the 6th Int. Conf. on Jojoba and its Uses. Beer-Sheva, Israel. Ben Gurion University of the Negev, 1984, pp. 253-260.

[10] A. Benzioni, "Jojoba Institute for Applied Research" Ben Gurion University of the Negev, Israel, pp. 1-6, 1997.

[11] M. A. Bashir, A. M. Iqbal, M. N. Asad, M. Y. Ranam, and S.F.H. Shah, " Propagation of jojoba through cuttings" J. Animal \& Plant Sci., vol. 11, pp. 24-29, 2001.

[12] K. A. Gomez, A. A, Gomez, "Statistical procedures for agricultural research" John Wiley \& Sons, New York, pp. 298-308, 1983.

[13] E. V. D. Sastry, "Essentials of Agricultural Statistics" Pointer Publishers, Jaipur (India), p.p 260-266, 2007.

[14] A.M. Eed, A.H. Burgoyne, "Effect of different rooting media and plant growth regulators on rooting of jojoba (Simmondsia chinensis (Link) Schneider) semi-hard wood cuttings under plastic tunnel conditions" In: Sandhu, S. \& Yingthawornsuk, T. (eds) Proc. of the Int. Conf. on Agri., Eco., and Medic. Sci., 6-7 February, Bali, Indonesia, pp 14-17, 2014.

[15] A. M. Eed, A.H. Burgoyne, "Propagation of Simmondsia Chinensis (Link) Schneider by stem cuttings" Biological and Chemical Research, Vol., 2015, p. 268-275, 2015. 